\title{
IDENTIFIKASI FASILITAS SEKOLAH DASAR BERSIH SEHAT: STUDI PADA MADRASAH IBTIDAIYAH KOTA BANDAR LAMPUNG
}

\author{
Samino ${ }^{1}$, Chritin Angelina Febriani ${ }^{1}$, Eva Finarika ${ }^{2}$
}

\begin{abstract}
ABSTRAK
Kesehatan sekolah dalam lingkungan sekolah dasar menjadi hal yang penting, usia anak sekolah dasar menjadi usia yang rentan terhadap masalah kesehatan dan tumbuh kembang anak sangat signifikan. Menjaga kesehatan lingkungan sekolah harus memperhatikan sarana prasarananya di sekolah. Program Madrasah Ibtidaiyah Bersih Sehat (MIBS), oleh Kementrian Pendidikan dan Kebudayaan belum mampu meningkatkan mutu kesehatan sekolah/madrasah. Tujuan diketahui kualitas kelengkapan fasilitas UKS, CTPS dan Jamban di lima Madrasah Ibtidaiyah Kota Bandar Lampung 2019. Penelitian deskriptif dengan pendekatan studi kasus. Sumber data primer dengan melakukan observasi, wawancara mendalam dan data sekunder dengan melakukan kajian dokumen madrasah. Hasil penelitian menunjukkan kualitas kelengkapan fasilitas di lima Madrasah Ibtidaiyah, UKS sebesar 20,21 (50,54\%) peringkat $C$ kategori cukup, CTPS sebesar 7,41 (37,07\%) peringkat D kategori kurang, jamban sebesar $24,60(61,50 \%)$ peringkat C kategori cukup. Sedangkan kualitas kelengkapan fasilitas dari ketiga fasilitas UKS, CTPS, dan jamban sebesar 52,23 dengan peringkat C kategori "Cukup". Dapat disimpulkan bahwa tingkat pencapaian kualitas kelengkapan fasilitas UKS, CTPS, dan jamban di madrasah masih rendah. Disarankan, kepala madrasah dapat melakukan kerja sama dengan pihak ketiga.
\end{abstract}

Kata kunci : Kelengkapan fasilitas, UKS, CTPS, Jamban

\section{ABSTRACT}

School health in the Madrasah Ibtidaiyah environment is important, participants are still in the golden age, are still vulnerable to health problems and need good health services so that their growth and development are not disrupted. The completeness of School Health Business facilities (UKS), hand washing facilities (CTPS), and latrine health greatly affect the health status of students. The purpose of this research is to know the quality of the completeness of the UKS, CTPS and latrine facilities in the Madrasah Ibtidaiyah in Bandar Lampung City 2019. Descriptive research with a case study approach. Primary data sources by conducting observations, and in-depth interviews. Analysis of descriptive data that yields measurable information. The results showed that the quality of completeness of facilities in five Madrasas Ibtidaiyah, UKS was 20.21 $(50.54 \%)$ C rating was adequate, CTPS was $7.41(37.07 \%)$ D rating was in the poor category, latrine was $24.60(61,50 \%)$ sufficient $C$ category rating. While the quality of completeness of facilities from the three UKS, CTPS, and latrine facilities is 52.23 with a $C$ rating in the "Fair" category. It can be concluded that the level of achievement of the quality of completeness of UKS, CTPS, and latrine facilities in madrasas is still low. It is recommended that the headmaster of madrasa can cooperate with third parties.

Keywords: Facilities UKS, CTPS, Latrine

\section{PENDAHULUAN}

Pendidikan menjadi bagian yang tidak dapat dipisahkan dari proses pembentukan karakter bangsa. Hal ini sesuai dengan UU No. 20 Tahun 2003 tentang Sistem Pendidikan Nasional Pasal (3). Pendidikan memiliki peran yang sangat penting, dengan pendidikan berkualitas berkaitan erat dengan sumber daya manusia yang berkualitas.

1. Fakultas Kesehatan Masyarakat Universitas Malahayati

2. Alumni Fakultas Kesehatan Masyarakat Universitas Malahayati 
Salah satu ciri sumber daya yang berkualitas adalah sehat, untuk mewujudkan peserta didik yang sehat diantaranya dengan penyelenggaraan kesehatan sekolah. Kesehatan sekolah dalam lingkungan sekolah dasar menjadi hal yang penting, karena usia anak sekolah dasar menjadi usia yang rentan terhadap masalah kesehatan dan tumbuh kembang anak yang sangat signifikan, salah satunya mengenai sarana dan prasarana di sekolah. Ketersediaan sarana prasarana/ sanitasi sekolah yang memadai akan memberikan dampak dalam pembangunan sektor kesehatan, pendidikan, kesetaraan gender, ekonomi, serta air dan sanitasi.

Berdasarkan data profil sanitasi sekolah dasar di Indonesia 34,90\% atau 51,485 sekolah dasar tidak memiliki sarana cuci tangan, $12,19 \%$ atau 17.983 sekolah tidak memiliki akses jamban, $56,41 \%$ atau 83,205 memiliki akses jamban namun terbatas atau tidak terpisah dan $31,40 \%$ atau 46,315 memiliki akses jamban dasar yaitu terpisah dan dalam kondisi yang baik atau rusak ringan. Selain itu untuk di Provinsi Lampung 29,15\% sekolah dasar yang tidak memiliki sarana cuci tangan pakai sabun dan $70,85 \%$ telah memiliki sarana, $8,25 \%$ sekolah dasar tidak memiliki akses jamban, 63,18\% memiliki akses jamban namun terbatas atau tidak terpisah dan $20,57 \%$ memiliki jamban. Indeks provinsi lampung 57,58 (indeks nasional 53,75), masih ada 42,42 yang belum mampu mengakses santasi dasar.

UNICEF Indonesia dalam ringkasan kajian air bersih, sanitasi, dan kebersihan mengatakan bahwa sanitasi dan perilaku kebersihan yang buruk berkontribusi terhadap $88 \%$ kematian anak akibat diare di seluruh dunia. Selain dapat menyebabkan penyakit diare, sanitasi yang tidak memadai, praktek kebersihan yang buruk, serta air yang terkontaminasi dapat menyebabkan penyakit lain yang meliputi disentri, kolera, tipus, hepatitis, leptospirosis, malaria, demam berdarah, kudis, penyakit pernapasan kronis dan infeksi parasit usus (Kementrian Pendidikan dan Kebudayaan, 2017). Diare merupakan penyakit kedua yang menyebabkan kematian pada anak-anak balita dibawah umur 5 tahun. Setiap tahunnya penyakit diare membunuh 525.000 anak dibawah 5 tahun (WHO, 2017). Prevalensi diare berdasarkan diagnosis tenaga kesehatan di Indonesia pada tahun 2018 sebanyak $8,0 \%$. Selain itu juga masih terdapat $40-$ $60 \%$ anak usia sekolah yang menderita penyakit cacingan (Kementerian Kesehatan, Badan Penelitian dan Pengembangan Kesehatan, 2018).

Berdasarkan Profil Kesehatan Indonesia tahun 2017 ditemukan kasus diare semua umur di Provinsi Lampung sebanyak 142.838 kasus, dan kasus diare di Kota Bandar Lampung pada tahun 2018 yang dikelompokan pada umur 5-9 tahun: 6.587 kasus, umur 1014 tahun : 3017 kasus (P2 Dinkes Kota Bandar Lampung, 2018). Fenomena tersebut membuktikan bahwa program Sekolah Dasar Bersih dan Sehat (MIBS) oleh Kementrian Pendidikan dan Kebudayaan melalui Direktorat Jendral Pendidikan Dasar ternyata belum mampu meningkatkan mutu kesehatan sekolah. Upaya mewujudkan program MIBS dapat dicapai salah satunya dengan melengkapi sarana dan prasarana sekolah/madrasah. Tujuan penelitian diketahui kualitas kelengkapan fasilitas sekolah bersih sehat (UKS, CTPS dan jamban) pada Madrasah Ibtidaiyah di Kota Bandar Lampung.

\section{METODE PENELITIAN}

Jenis penelitian desktiptif kualitatif, dengan pendekatan studi kasus. Penelitian dilakukan di lima Madrasah Ibtidaiyah Kota Bandar Lampung. Informan pimpinan/kepala madrasah ibtidaiyah. Pengumpulan data observasi, wawancara mendalam dan kajian dokumen dengan analisis diskriptif.

\section{HASIL PENELITIAN}

Berdasarkan tabel 1 diketahui nilai rata-rata kualitas kelengkapan fasilitas UKS di Madrasah Ibtidaiyah Kota Bandar Lampung, 20,21 (50,54\%) kategori "Cukup". Nilai tertinggi diperoleh M VI sebesar 38,78 (96,94\%), kategori "Sangat baik". Sedangkan untuk nilai terendah diperoleh $M$ IX sebesar $1,18 \quad(2,94 \%)$, kategori "Kurang". 
Tabel 1

Distribusi Kualitas Kelengkapan Fasilitas UKS di Madrasah Ibtidaiyah Kota Bandar Lampung 2019

\begin{tabular}{lccc}
\hline \multicolumn{1}{c}{ Madrasah } & Nilai Standar UKS & Hasil Observasi & $\mathbf{\%}$ \\
\hline M-III & 40 & 15,28 & 38,20 \\
M-VI & 40 & 38,78 & 96,95 \\
M-IX & 40 & 1,18 & 2,95 \\
M-HI & 40 & 25,85 & 64,63 \\
M-IA & 40 & 19,98 & 49,95 \\
Rata-Rata & & 20,21 & 50,54 \\
\hline
\end{tabular}

Tabel 2

Distribusi Kualitas Kelengkapan Fasilitas CTPS di Madrasah Ibtidaiyah Kota Bandar Lampung 2019

\begin{tabular}{lccc}
\hline Madrasah & NilaiStandar CTPS & Nilai Hasil Observasi & \% \\
\hline M-III & 20 & 9,98 & 49,90 \\
M-VI & 20 & 9,98 & 49,90 \\
M-IX & 20 & 4,28 & 21,40 \\
M-HI & 20 & 8,55 & 42,75 \\
M-IA & 20 & 4,28 & 21,40 \\
Rata-Rata & & 7,41 & 37,07 \\
\hline
\end{tabular}

Berdasarkan tabel 2 diketahui nilai rata-rata kualitas kelengkapan fasilitas CTPS di Madrasah Ibtidaiyah Kota Bandar Lampung yaitu 7,41 $(37,07 \%)$, kategori kurang. Nilai tertinggi diperoleh M-III dan M-VI sebesar 9,98 (49,90\%). Sedangkan untuk nilai terendah diperoleh M-IX dan M-IA sebesar $4,28(21,40 \%)$. Fasilitas CTPS nilai tertinggi dan terendah masih dalam kategori "Kurang".

Tabel 3

Distribusi Kualitas Kelengkapan Fasilitas Jamban di Madrasah Ibtidaiyah Kota Bandar Lampung 2019

\begin{tabular}{lccc}
\hline Madrasah & Nilai Standar Jamban & Nilai Hasil Observasi & \% \\
\hline M-III & 40 & 30,00 & 75,00 \\
M-VI & 40 & 26,00 & 65,00 \\
M-IX & 40 & 29,00 & 72,50 \\
M-HI & 40 & 15,00 & 37,50 \\
M-IA & 40 & 23,00 & 57,50 \\
Rata-Rata & & 24,60 & 61,50 \\
\hline
\end{tabular}

Berdasarkan tabel 3 diketahui nilai rata-rata kualitas kelengkapan fasilitas jamban di Madrasah Ibtidaiyah Kota Bandar Lampung 24,60 (61,50\%), kategori "Cukup". Nilai tertinggi diperoleh M-III sebesar 30,00 (75,00\%), kategori "Baik". Sedangkan untuk nilai terendah diperoleh $\mathrm{M}$-HI sebesar 15,00 $(37,50 \%)$, kategori kurang.

Berdasarkan tabel 4 diketahui rata-rata nilai akhir kelengkapan fasilitas MIBS yang meliputi komponen fasilitas
UKS, CTPS, dan jamban dari kelima Madrasah Ibtidaiyah Kota Bandar Lampung rata-ratanya 52,23 dengan peringkat C, kategori "Cukup". Sedangkan nilai tertinggi diperoleh M-VI dengan nilai akhir 74,76 dengan peringkat B, kategori "Baik", dan M-IX merupakan madrasah dengan nilai akhir terendah 34,46 dengan peringkat $D$ kategori "Kurang", hal ini juga terjadi pada M-HI dan M-IA. Secara umum dapat disimpulkan kualitas kelengkapan 
UKS, CTPS, dan jamban di lima Madrasah Ibtidaiyah Kota Bandar

Lampung masih rendah

dengan

peringkat C kategori "Cukup".

Tabel 4

Distribusi Kualitas Kelengkapan Fasilitas MIBS di Madrasah Ibtidaiyah Kota Bandar Lampung 2019

\begin{tabular}{lcc}
\hline Madrasah & Nilai Akhir & Peringkat \\
\hline M-III & 55,26 & $\mathrm{C}$ \\
M-VI & 74,76 & $\mathrm{~B}$ \\
M-IX & 34,46 & $\mathrm{D}$ \\
M-HI & 49,40 & $\mathrm{D}$ \\
M-IA & 47,26 & $\mathrm{D}$ \\
Rata-Rata & 52,23 & $\mathrm{C}$ \\
\hline
\end{tabular}

\section{PEMBAHASAN}

\section{Kualitas Kelengkapan Fasilitas UKS}

Berdasarkan uraian kualitas

kelengkapan UKS di Madrasah Ibtidaiyah

Kota Bandar Lampung baru mencapai 50,54\%, kategori "Cukup". Hasil menunjukkan derajat kualitas UKS dilokasi penelitian masih dalam kategori rendah. Hal ini belum sejalan dengan ide bahwa madrasah harus memili UKS yang cukup baik sebagai tempat pelayanan dan kegiatan promotif preventif lainya. UKS merupakan unit usaha yang dilakukan oleh madrasah dalam rangka untuk meningkatkan kesehatan peserta didik pada setiap jenjang pendidikan. Penyediaan fasilitas UKS disesuaikan dengan Peraturan Menteri Pendidikan Nasional No. 24 tahun 2007 dan Peraturan Menteri Kesehatan nomor 1429/Menkes/SK/XII/2006 tentang Pedoman Penyelenggaraan Kesehatan Lingkungan Sekolah, bahwa sekolah/madrasah harus memiliki UKS dan melengkapi sarana dan prasaran yang diperlukan, untuk memberi pelayanan bagi warga madrasah yang memerlukan bantuan kesehatan. Pelayanan tersebut sangat penting, karena mampu membantu mengurang penderitaan orang lain lain yang membutuhkan. Misalnya ada siswa yang luka akhibat tergesek benda tumpul maupun tajam, UKS mampu memberikan pertolongan, dengan ketidak adanya fasilitas dan sarana, maka kurban tidak bisa memperoleh pertolongan.

Hasil penelitian ini sesuai dengan Nurhayu, et,al (2018), bahwa SD di Kecamatan Tembalang, telah memiliki sarana prasarana untuk UKS, sebagian besar belum memiliki ruang UKS $(84,8 \%)$, serta beberapa sekolah yang sudah memiliki ruang UKS keadaannya belum memenuhi syarat. Sekolah masih belum melengkapi perabotan perlengkapan yang dibutuhkan di ruang UKS.

Hasil observasi terhadap 17 sub indikator penilaian UKS didapatkan ada satu madrasah yaitu M-IX Bandar Lampung, sampai saat ini belum memiliki bentuk fisik ruang UKS. Selain tidak memiliki bentuk fisik ruang UKS, indikator lainnya pun tidak terpenuhi atau tidak ada keberadaannya, seperti tempat tidur, buku administrasi/UKS, tandu, snellen chart, model gigi dan torso rangka. Kedua terendah untuk nilai observasi sub fokus UKS yaitu pada $\mathrm{M}$ IA, hal ini dikarenakan ruang UKS yang sudah ada tidak digunakan sebaik mungkin. Sedangkan M-III Bandar Lampung mendapat nilai observasi terendah ke tiga untuk sub fokus ruang UKS, hal ini dikarenakan keadaan ruang UKS yang digunakan untuk sementara waktu, juga digunakan juga sebagai pos keamanan dan gudang (tempat menyimpan barang perlengkapan madrasah), pada hal kondisi ruangan kecil, pengap/tidak ada ventilasi yang cukup, tidak memiliki snellen chart, model gigi, torso rangka, thermometer, tandu dan tempat sampah. Untuk indikator sub kelengkapan fasilitas UKS yang telah terpenuhi oleh lima Madrasah Ibtidaiyah di Kota Bandar Lampung hanya termometer dan P3K. Selain jumlah dan kelengkapannya, yang lebih 
penting adalah kualitas sarana tersebut, dan pada umumnya masih rendah.

Untuk memenuhi indikator kelengkapan serta meningkatkan kualitas kelengkapan fasilitas UKS menjadi lebih baik, disarankan pimpinan/kepala madrasah selain melakukan kerjasama dan menyisihkan dana untuk membeli perlengkapan UKS, ada hal yang tidak kalah penting, yaitu jangan menyatukan dengan fungsi lain seperti keamanan maupun gudang madrasah.

\section{Kualitas Kelengkapan Fasilitas CTPS}

Berdasarkan uraian nilai kualitas kelengkapan CTPS di Madrasah Ibtidaiyah Kota Bandar Lampung, baru mencapai 37,07\%, kategori "Kurang". Sarana cuci tangan pada sekolah/madrasah sangat penting, karena banyaknya kumunitas dan aktifitas warganya tinggi, sehingga sangat memerlukan sarana tersebut. Sarana cuci tangan dilengkapi dengan sabun dan dimanfaatkan dengan baik akan mengurangi resiko terjadinya penyakit, misalnya deare, cacingan, setiap orang.

Mencuci tangan dengan sabun adalah salah satu tindakan sanitasi dengan membersihkan tangan dari jari jemari menggunakan air (sebaiknya mengalir) dan sabun, mencuci tangan dengan sabun juga dapat lebih efektif menghilangkan kotoran dan debu secara mekanis dari permukaan kulit, mengurangi jumlah mikroorganisme penyebab penyakit seperti virus, bakteri dan parasit lainnya pada kedua tangan (Maryunani, 2018). Dalam penyediaan fasilitas CTPS disesuaikan dengan standar Peraturan Kementrian Pendidikan dan Kebudayaan dan Peraturan Menteri Kesehatan No.3 Tahun 2014 tentang Sanitasi Total Berbasis Masyarakat.

Hasil penelitian Santi dan Al-Bahij (2018), tempat cuci tangan di tiga SD negeri $80 \%$ telah memenuhi standar kesehatan yang telah di tetapkan. Tetapi dari semua tempat cuci tangan di ketiga sekolah tidak ada yang menyediakan sabun. Terdapat satu sekolah yang tempat cuci tangannya hanya menggunakan ember. Selain itu, ada satu sekolah tempat cuci tangannya tidak berfungsi, disebabkan keran air rusak dan salurannya mampet.

Hasil observasi terhadap 7 sub indikator penilaian sarana CTPS hanya satu madrasah, M-VI Bandar Lampung yang memiliki washtafel di lingkungan sekolahnya, walaupun hanya beberapa yang berfungsi. Pada $\mathrm{M}$-HI untuk pengadaan fasilitas CTPS memanfaatkan galon air minum yang diletakkan di depan kelas. Sedangkan di kedua madrasah, M-IX Bandar Lampung dan MI- IA memperoleh nilai terendah. Indikator sub kelengkapan lainnya yang belum memenuhi persyaratan adalah belum tersedianya sabun cuci tangan, kecuali M-III yang menggunakan pembersih pengganti sabun berupa hand sanitizer.

Untuk memenuhi indikator kelengkapan serta meningkatkan kualitas kelengkapan fasilitas CTPS menjadi lebih baik, disarankan agar pimpinan/kepala madrasah dapat menggerakkan warga sekolah untuk lebih memanfaatkan fasilitas CTPS, dengan cara edukasi dan praktik CTPS berkelompok, penjelasan materi langkah CTPS menggunakan lagu/video. Pilihan lain dari minimnya biaya untuk memenuhi fasilitas CTPS yaitu mengganti washtafel dengan sumber air sistem perpipaan, sumber air non pipaan dapat menggunakan wadah penampungan air bersih tertutup yang cukup untuk dipakai beberapa kali (Ember, gentong, drum sedang, jrigen, galon) yang diberikan lubang saluran keluarnya air atau kran, air bekas CTPS dapat dialirkan ke pembuangan air dengan sambungan pipa langsung lalu dialirkan ke pembuangan.

\section{Kualitas Kelengkapan Fasilitas Jamban}

Berdasarkan uraian nilai kualitas kelengkapan jamban di Madrasah Ibtidaiyah Kota Bandar Lampung baru mencapai 61,50\%, kategori "Cukup". Jamban adalah suatu ruangan yang mempunyai kualitas fasilitas pembuangan kotoran manusia, memelihara kebersihan jamban yaitu menjadikan lingkungan tetap bersih, sehat dan tidak berbau, tidak mencemai sumber air yang ada di sekitarnya, tidak mengundang datangnya serangga yang 
menularkan penyakit (Maryunani, 2018). Dalam penyediaan fasilitas jamban disesuaikan dengan standar Peraturan Menteri Pendidikan Nasional No. 24 tahun 2007 dan Peraturan Menteri Kesehatan 1429/Menkes/SK/XII/2006 Pedoman Penyelenggaraan nomor Lingkungan Sekolah.

Hasil penelitian berbeda dengan Santi dan AL-Bahij (2018), menyatkan bahwa kondisi jamban telah memenuhi standar sudah banyak $(83,3 \%)$, akan tetapi perbandingan rasio jamban dengan siswa belum memenuhi standar. Rasionya 1:40. Hasil penelitian lain terkait jamban yang telah dilakukan oleh Relisa (2016), memperoleh hasil kepemilikan jamban belum mencapai standar yang telah ditentukan, yaitu $(50,60 \%)$. Beberapa sekolah tidak memiliki gantungan pakaian dan tempat sampah, sedangkan kedua prabot tersebut sangat penting dalam menunjang aktivitas jamban.

Hasil observasi terhadap 20 sub indikator penilaian didapatkan fasilitas jamban sudah terpenuhi di lima madrasah dan ketersediaan jamban guru dan siswa di lima madrasah sudah terpenuhi. Hanya saja rasio perbandingan di lima madrasah masih belum sesuai dengan Peraturan Menteri Pendidikan Nasional No. 24 tahun 2007 dan Peraturan Menteri Kesehatan nomor 1429/Menkes/SK/XII/2006 tentang Pedoman Penyelenggaraan Kesehatan Lingkungan Sekolah. Untuk nilai observasi tertinggi pada sub fokus jamban yaitu pada M-III Bandar Lampung, hal ini dikarenakan jamban belum lama di lakukan rehab/perbaikan, sedangkan untuk nilai observasi terendah pada sub fokus jamban pada M-HI, hal ini dikarenakan keadaan jamban yang sangat memprihatinkan. Hanya terdapat 3-4 jamban saja yang dapat digunakan untuk fasilitas gabungan MI, MTs dan MA, tidak ada pintu, kualitas dinding retak dan rapuh. Warna cat pudar, berbau dan kotor.

Untuk indikator sub kelengkapan lainnya yaitu ketersediaan gayung, kapstop, sikat wc, dan tempat sampah dalam penelitian ini ke lima madrasah hanya memiliki satu atau dua macam alat seperti hanya tersedia gayung, sikat
WC ataupun tempat sampah saja, ini menjadikan nilai hasil pada sub indikator ini rendah. Untuk memenuhi indikator kelengkapan serta meningkatkan kualitas kelengkapan fasilitas jamban menjadi lebih baik, saran peneliti penyebaran informasi melalui media KIE tidak kalah penting dari edukasi yang diberikan oleh guru/tenaga pendidik agar siswa cepat tanggap dan mudah mengingat, seperti pemasangan poster tata-tertib pengguna jamban yang baik dan benar, pentingnya menjaga kebersihan, juga mengatur jadwal piket peserta didik per-hari per-rombongan belajar untuk membersihkan jamban. Pemisahan jamban laki-laki dan perempuan harus dilakukan walaupun rasio antara jumlah siswa belum sesuai dengan jamban.

\section{Kualitas Kelengkapan Fasilitas MIBS}

Berdasarkan hasil penilaian kualitas kelengkapan fasilitas MIBS (UKS, CTPS dan jamban) dari kelima madrasah tersebut dengan rata-rata 52,23 peringkat C, kategori "Cukup". Nilai tertinggi diperoleh M-VI 74.76, peringkat $B$, terendah M-IX, 34.46 peringkat $D$.

Untuk memenuhi indikator kelengkapan serta meningkatkan kualitas kelengkapan fasilitas MIBS menjadi lebih baik, disarankan pimpinan/kepala madrasah dapat bekerja sama dengan komite maupun masyarakat (dunia usaha, perguruan tinggi, maupun masyarakat sekitar). Kerja sama dapat berbentuk bantuan finansial maupun bentuk-bentuk lain yang mendukung keberhasilan MIBS. Selain itu, kepala madrasah perlu membuat kebijakan untuk mendukung agar semua warga madrasah harus berperilaku hidup bersih dan sehat, berperan aktif dalam menjaga kebersihan lingkungan dan sarana prasarana/fasilitas madrasah.

$\mathrm{Hal}$ ini sejalan dengan Kementrian Pendidikan dan Kebudayaan melalui Direktorat Jendral Pendidikan Dasar, untuk mewujudkan program MIBS dapat dicapai melalui strategi penyediaan sarana dan prasarana, manajemen yang baik, penciptaan kondisi ideal dengan melibatkan partisipasi semua pihak warga sekolah, 
komite sekolah/madrasah, puskesmas setempat, dan masyarakat 2013.

\section{Strategi pemenuhan kualitas kelengkapan fasilitas MIBS}

Hasil kajian komponen fasilitas MIBS UKS, CTPS dan Jamban dapat disimpulkan tingkat kualitas kelengkapan fasilitas dari lima Madrasah Ibtidaiyah di Kota Bandar Lampung baru mencapai 52,23 kategori "Cukup".

Berdasarkan hasil wawancara mendalam dari ke lima pimpinan/Kepala Madrasah Ibtidaiyah, diperoleh informasi bahwa tiap madrasah memiliki masalah yang berbeda-beda. Strategi untuk memecahkan masalah berbeda-beda pula, namundapat di klasifikasikan menjadi strategi internal dan eksternal. Strategi internal mencakup kerjasama semua warga madrasah, untuk bersamasama menjaga kebersihan dan memperbaiki atau menambah sarana dan prasarana madrasah dari sebagian dana operasional. Selanjutnya strategi eksternal yaitu kerjasama yang ingin dilakukan dengan pihak ke-3 seperti komite, pengajuan proposal kepada pemerintah, institusi atau lembaga swadaya masyarakat untuk meningkatkan pemenuhan kualitas kelengkapan fasilitas MIBS.

Hemat peneliti, strategi-strategi yang akan dilakukan oleh kelima Madrasah Ibtidaiyah tersebut baik, seperti strategi internal, akan melakukan kerjasama antar warga madrasah, untuk mendukung kebijakan pimpinan, merawat dan memelihara, serta menciptakan pemenuhan fasilitas MIBS. Memantapkan dan memperbaiki sistem dan pemenuhan internal madrasah terlebih dahulu. Strategi eksternal tidak kalah penting bahkan dapat dikembang dengan melibatkan kerjasama berbagai pihak, seperti masyarakat sekitar, institusi pendidikan tinggi, komite madrasah, puskesmas, dunia usaha, pemerintah pusat maupun daerah, dan lain-lain, untuk mendukung dan mendorong program-program atau kegiatan yang akan dilaksanakan madrasah untuk mencapai derajat madrasah sehat.

\section{KESIMPULAN}

Berdasarkan uraian di atas dapat disimpulkan bahwa kualitas kelengkapan sarana dan prasarana untuk UKS, CTPS, dan jamban masih tergolong rendah, kategori cukup. Hal ini dibuktikan bahwa kualitas UKS baru mencapai peringkat C kategori cukup, CTPS peringkat D kategori kurang, dan jamban peringkat $C$ kategori cukup. Strategi untuk pemenuhan kualitas sarana dan prasana tersebut pimpinan/kepala madrasah akan mengoptimalkan kekuatan internal dan akan memanfaatkan peluang kerja sama berbagai pihak seperti komite, dunia usaha, perguruan tinggi, serta masyarakat sekitar.

\section{SARAN}

$\begin{array}{cc}\text { Pimpinan/kepala } & \text { madrasah } \\ \text { diharapkan dapat membuat }\end{array}$ pengembangan kebijakan atau peraturan serta kerja sama dengan pihak ketiga yang dapat mendukung program MIBS seperti menjaga lingkungan dan sarana prasarana/fasilitas madrasah, memperkuat peran dan fungsi UKS untuk melakukan monitoring ketersediaan sarana dan prasarana UKS, CTPS, dan Jamban sehat.

\section{DAFTAR PUSTAKA}

Dinas Kesehatan Kota Bandar Lampung, (2018). Laporan Evaluasi Program P2. Kota Bandar Lampung 2018, Bandar Lampung

Enikmawati, Anik \& Aslamah, Fatihah, (2017). Hubungan Antara Perilaku Cuci Tangan Dengan Kejadian Diare Pada Anak Sd, Jurnal Penelitian, Keperawatan-Stikes Muhammadiyah, Surakarta.

Harmawan, Dimas, (2015). Tingkat Keterlaksanaan Usaha Kesehatan Sekolah (Uks) Pada Sekolah Dasar Negeri Se Kecamatan Kokap Kabupaten Kulonprogo Tahun Ajaran 2014/2015, Skripsi, PGSD Jasmani-UNV, Yogyakarta

Kementerian Pendidikan dan Kebudayaan, (2013). Panduan Pembinaan Sekolah Dasar Bersih Dan Sehat Direktorat Jendral Pendidikan Dasar, Jakarta.

Kementerian Kesehatan RI, (2014). Peraturan Menteri Kesehatan 
Republik Indonesia Nomor 3 Tentang Sanitasi Total Berbasis Masyarakat

Kementerian Pendidikan dan Kebudayaan, (2017). Profil Sanitas Sekolah Tahun 2017. Direktorat Jendral Pendidikan Dasar Dan Menengah, Jakarta

Kementerian Kesehatan Badan Penelitian dan Pengembangan Kesehatan, (2018). Hasil Utama Riskesdas 2018, Jakarta

Maryunani, Anik, (2018). Perilaku Hidup Bersih dan Sehat (PHBS), Trans Info Media Jakarta.

Menteri Kesehatan RI, (2007). Pedoman Penyelenggaraan Kesehatan Lingkungan Sekolah Nomor 1429/MENKES/SK.XII/2006, Jakarta

Nurhayu, Et,Al, (2018). Pelaksanaan Trias Usaha Kesehatan Sekolah Pada Tingkat Sekolah Dasar Di Wilayah Kecamatan Tembalang Kota Semarang, Junal R Kesehatan Masyarakat (E-
Journal) Volume 6 Nomor 1, Januari 2018 (ISSN:2356-3345)

Relisa, (2016). Kajian Prasarana Pendidikan Sekolah Dasar Sebagai Salah Satu Indikator Pencapaian Standar Nasional Pendidikan Study Of Primary School Infrastructure As One Of Indicator In. Pendidikan Dan Kebudayaan, Jurnal Pendidikan Dan Kebudayaan, Vol 1, Nomor 1 April 2016

Kementrian Pendidikan Nasional RI, (2007). Standar Sarana dan Prasarana Untuk Sekolah, Jakarta.

Santi, Apri, Utami Parta., AL-Bahij, A. (2018). Kondisi sanitasi di tiga sekolah dasar negeri di daerah tanggerang selatan. Hoistika Jurnal IImiah PGSD, 2 No.1 Mei, $30-36$.

WHO, (2017). Diarrhoeal Disease. https://www.who.int/ diakses 13 Maret 2019 